\title{
2
}

\section{Coalitions and Consequences: Learnership and Leadership in India, 1948-2008}

\author{
Robin Jeffrey
}

Do coalitions exacerbate or mitigate the apparent confusion of life in India?

(Mansingh, S., 2007)

This essay attempts to explore a missing aspect of the large literature that has grown up around coalition governments in India and then to include that aspect in a discussion of the consequences of coalition governments. Are they good or bad for economic development, social change and honest, effective government? Do they work better at the state level rather than the national?

The missing aspect is the 'educational process' by which Indian politicians have learned the benefits and requirements of coalition governments and then how to make them work. I argue that such a process began in the state of Kerala, took nearly a generation to 'learn' and partly depended on the availability (and talents) of individual leaders. The same educational process that fostered understanding of the rewards that coalitions can bring also sensitised politicians to the need to deliver goods to their constituents. This need to satisfy voters leads to consideration of questions about the 'goodness' or 'badness' of coalitions.

In arguing that the educational process has been overlooked in study of coalitions in India, I am not discounting other aspects. I would particularly acknowledge the fragmentation of Indian politics as sub-regions and previously marginal and illiterate groups have produced people who understand the political system and are able to work effectively within it. Potent local political parties emerge and it becomes difficult to create a powerful state-wide party, much less a powerful national party.

\subsection{Coalitions in Kerala: Learnership and Leadership}

Although the state of Kerala accounts for less than three per cent of India's population (about 32 million out of 1100 million), it has acquired notoriety for its 'model' of economic development and for its election of a Communist government in 1957. Kerala also 'learned' coalitions before the rest of India.

Kerala had to. The composition of the state and its social structure were in some ways a microcosm of India. To begin with, Kerala state of the Indian Union was created only in 1956 by the joining of two old princely states (Travancore, the large southern half, and pint-sized Cochin in the middle) and the British-ruled district of Malabar in the north. In each of the old units, sentiments and interests made people conscious of 'their' particular place, however much the Malayalam language and an overarching Malayali culture may have made a united Kerala seem a good idea. 
Kerala was also socially segmented, highly literate and widely mobilised, even at independence. The population was roughly 20 per cent Muslim, 20 per cent Christian, 20 per cent high-caste Hindu and 40 per cent lower-caste Hindu. But Muslims were concentrated in Malabar district; Christians of various sects in Cochin and central and north Travancore. Churches, education societies and social organisations tended to work most effectively within the administrative unit where they originated.

The most notable exception to the latter statement was the Communist Party of India (CPI). Often banned from the 1930s to the 1950s, the CPI used different jurisdictions to enable members to slip between the butterfingers of different police forces and continue their agitations. Sympathisers of the Indian National Congress (INC) were present in all three units, but they had few of the links or reasons for cooperation that the Communists had.

The three-dimensional patchwork of Kerala - jurisdictions, social groups and political and social organisations - looked in some ways like India in miniature. But high levels of literacy and social upheaval (the result, in part, of the collapse of the matrilineal family system that affected a large proportion of Hindus) accelerated participation in politics. First, the national movement against princely rule (or the British) drew people into action and organisation. After 1947, the struggle between Communists and the Congress brought political activity to every village.

Travancore held the first universal-suffrage elections in India in February 1948. The Travancore State Congress, loosely affiliated to the Indian National Congress, was inundated with members prior to the elections and scored a huge victory, taking 56 seats without a contest and winning 41 out of 61 contested seats with 48 per cent of the vote. ${ }^{1}$ It formed a government under the man who led the anti-princely movement; but the government collapsed in six months. Over the next 22 years, residents of the Travancore area experienced a dozen governments and three periods of President's Rule from New Delhi. No government served a full term. ${ }^{2}$ Between 1970 and 2007, however, Kerala governments have completed their full five-year terms on six occasions. ${ }^{3}$

Why did Kerala produce such unstable government in the earlier when in the rest of India, the period from 1947-67 was controlled by the Congress Party, and political scientists characterised this as an era of a 'dominant-party system’?

First, almost nowhere else in India had a political challenge to the Congress comparable to that of the Communist Party. This competitive struggle mobilised groups for politics. People were exhorted to identify with 'their party' — or their religion or their caste. Because literacy was high (40 per cent of the total population in 1951) and newspapers readily available, such exhortations went wide and deep in ways that other areas of India did not replicate until a generation later.

Thus the ingredients existed for locally based political organisations, calling themselves 'parties' and claiming state-wide reach though having a genuine base only in a small area. Such 'parties' split off from both left and

1 Travancore Government Gazette, Part 2, 2 March 1948, pp. $127 \mathrm{ff}$.

2 Travancore and Cochin were merged to form Travancore-Cochin in 1949. They in turn merged with Malabar District in 1956 to form Kerala. Tamil-speaking districts in the south were joined with Madras state (now Tamil Nadu).

The Official Web Portal of Govt. of Kerala, Political Background, <http://www.kerala. gov.in/> (7 August 2007). 
right of politics. They gave themselves names like 'the Kerala Congress' and often added bracketed initials or names to identify the leader who was running the group — for example, Kerala Congress (Mani).

Second, political leaders had to discover what the consequences of particular behaviours were. To illustrate, let me focus on Pattom A. Thanu Pillai (1885-1970). Thanu Pillai had three occasions as Chief Minister - of Travancore for a few months in 1948, of Travancore-Cochin for a few more months in 1954-55, and nearly two years in 1960-62; each government ended in collapse. Other politicians looked on and perhaps some learned. Thanu Pillai came from a background typical of India's ‘freedom struggle' elites. He came from a higher caste (a Nair), and he was a lawyer, well-read in English. His critics said he was inspired by the haughtiness of princelings of old and behaved more like a Dewan (a prince's prime minister) than a democratic politician. He had been a European-dressed lawyer, practising in the Travancore courts, until 1938 when he joined the Travancore State Congress to give it the social variety it desperately needed. (To claim wide backing, it needed the support of higher-caste Hindus.) He and his colleagues caused consternation in sleepy Trivandrum when they first appeared in the local legislature wearing khadi - 'cloth which till two days back they would have barked at', according to a critic. ${ }^{4}$

Thanu Pillai, though a distinctive product of south Travancore, brought to legislative politics after independence expectations that were characteristic of many state politicians of his generation and experience. As lawyers, they were steeped in English legal precedent and British parliamentary history. They had, one might argue, swallowed the myth of 'the British party system', which suggested that political parties, once formed, behaved as disciplined units, piloted by their leaders as if they were ships. Added to such impressions was their own experience of the national movement. The Congress had emerged as the unquestioned force in Indian politics and Gandhi as the 'father of the nation.' In spite of the dissensions and desertions of the 1937-39 Congress governments in the provinces, there was nevertheless a sense that leaders like Gandhi should be followed. By extension, if a person were the Gandhi of his or her region, shouldn't such person be followed too? Such aloofness and expectations appeared to characterise Thanu Pillai.

Thanu Pillai's first short-lived Chief Ministership in 1948 ended quickly: an overwhelming Congress majority fragmented in a few months and the government fell. He left the Congress Party to become a 'socialist' and in effect took over the local franchise of one of the Indian socialist parties. Leading the Praja Socialist Party (PSP), he became coalition Chief Minister in 1954-55 and again in 1960-62 at the head of a coalition that had defeated the Communists in mid-term elections in 1960.

Thanu Pillai and those like him lacked the ideological glue to hold legislative alignments together and had not acquired the realisation of how much there was to lose by uncompromising positions. Old elites, as embodied by Thanu Pillai, had experiences and beliefs that encouraged them to take such positions; they also had connections, resources and professions that gave them something to fall back on if governments fell apart. Increasingly, however, this was not true of scores of Members of Legislative Assemblies who were being elected in Kerala. They came from less affluent circumstances, they saw politics as a career in itself, not the outcome of a career. And they began to see the defects of the inability to sustain governments.

\footnotetext{
${ }^{4}$ Sri Mulam Assembly Proceedings, vol. 12, 13 July 1938, p. 161.
} 
Thanu Pillai's reputation saw him appointed to a Governor's post in $1962,{ }^{5}$ and in the next eight years, Kerala politics experienced three elections and two periods of President's Rule. The Communist Party itself split in 1964 into a CPI and a CPI (Marxist). The ideological commitment that had been a Communist strength left the two new parties bitterly divided for years.

The fruits of Kerala's unplanned 'learning experience' began to show in 1969 and owed a good deal to a changed political style and sense of expectations, again embodied, for my purposes, in a particular politician. C. Achutha Menon (1913-91) became Chief Minister briefly in 1969 after the collapse of multi-party coalition elected in 1967. After mid-term elections in 1970 again failed to produce a victory for any party, Achutha Menon assumed leadership of what appeared an unlikely and ramshackle coalition. It ruled, however, for seven years, and Achutha Menon became the longest serving Chief Minister of the state. Kerala's era of stable coalition government began.

How had this happened? Experience and personality are part of an answer. On the surface, Achutha Menon and Thanu Pillai were similar: both were Nairs; both were lawyers. But Achutha Menon was from the more cosmopolitan area of Cochin State. As a Communist he had been underground evading the police in the late 1940s. He had been Finance Minister in the 1957-59 Communist government and stayed with the Moscow-line Communist Party of India when the Party split in 1964. Achutha Menon was also reputed to be cool-headed, erudite and honest — and, though he was only 57 in 1970, to have a bad heart.

By 1970, Kerala politicians perceived that there were few advantages for them personally in unstable governments - or indeed, long periods of President's Rule under bureaucrats. The lesson was becoming clear that compromise on a basic common program would allow the fruits of office to be tasted for a full five-year term. Such fruits were, and are, worth having - salary, offices, expenses, travel, telephones, cars and great possibilities for patronage and influence.

My argument is that in 1970 two conditions for stable coalitions were fulfilled in Kerala. First, an appreciation had emerged among many politicians that if power was to be hung onto for a beneficial period, compromises and adjustments were essential. Ideological purity, or unrestrained self-interest, were both counterproductive. The argument is not that hundreds of political aspirants suddenly came to this realisation, but, rather, that more than twenty years' experience of brief governments had taught such lessons. Second, to make such adjustments possible, there needed to be an acceptable, experienced leading figure - much more than a figurehead but less than a potential all-in-all dominator of the Indira Gandhi kind. Kerala's experience from 1948 had accelerated the education of politicians in some unwritten rules of coalition survival, and Achutha Menon's reputation and background made him the right sort of leader. The government he formed in 1970 remained in office for nearly seven years, its life extended by Indira Gandhi’s ‘emergency’ of 1975-77.

The 1970-77 government had its share of crises and confrontations. But they were resolved without threatening the government, largely as a result of a delicate equation. It was widely perceived that a figure comparable to Achutha Menon was not readily available, and this perception grew with his reputation. The longer he was Chief Minister, and the longer the ministry worked moderately effectively, the greater the 'irreplaceable factor' became. Achutha Menon, too, cultivated the impression that his health was not good and

\footnotetext{
${ }^{5}$ Governor of Punjab in 1962 and of Andhra Pradesh from 1964-68.
} 
his ambitions were few; he could leave the job if his colleagues did not want him. Such apparent detachment added to his authority, and such authority strengthened the glue that held the coalition together.

From 1970, Kerala has had a virtual two-party system with alternating coalition governments, built around the pole of the either the Congress Party or Communist Party of India (Marxist).

\subsection{The Consequences of Coalitions: Kerala}

What sort of government can such fragile entities provide? Kerala is frequently known for its 'Kerala model', a term which arises from remarkable social statistics: high literacy and life expectancy, a sex ratio favouring women, low infant mortality and a falling birthrate.

One of the causes is often held to be Kerala's political environment, characterised by 'public action', to use the phrase of Amartya Sen. 'Public action' requires that citizens be capable of organising and exerting pressure on their governments. In celebrated examples, Maternal and Child Health centres, if closed for more than a day or so, would provoke demonstrations of angry locals, organised by political parties that were out of power (Mencher 1980: 1781-2). Members of the Legislative Assembly (MLAs), elected from territorial constituencies, acquired a strong interest in being able to show voters that they were delivering the goods in the form of health services, housing, schools, colleges, bridges, roads and transport. The delicately poised nature of politics meant that MLAs had leverage in the capital because the threat of loss of support of even a few could generate an annoying, even fatal, crisis for a government. Thus the 1970 government pursued a well-publicised land reform that gave security of tenure to every landless labourer living on what had previously been landlord's land. And the 'one lakh housing' scheme aimed to build 100,000 houses for homeless, or poorly housed, families (Jeffrey, 2001: 176-82, 204-09).

If the social and political consequences of coalitions in Kerala could produce positive results, the economic results are usually considered less positive or fruitful. ${ }^{7}$ Kerala's economy, based on agricultural raw materials and the export of its skilled people, depends on remittances from Malayalis working elsewhere in India or overseas. In spite of its high levels of literacy, Kerala lags well behind Indian states like Karnataka, Tamil Nadu and Gujarat in economic development. The computer industry grew up in Bangalore; call-centres, around Bangalore and Delhi; Kerala, if anything, has lost some of its traditional basic industries, like processing of cashew-nut, to neighbouring states with lower wages and laxer labour laws.

The explanation often advanced is that Kerala's coalition governments have been unable to maintain order and implement far-sighted policies among a fractious, politically alert population. If police intervene in a labour dispute on the side of capital, the argument runs, political forces will force a coalition government to back down. One of the striking examples, which helped to cement this reputation throughout India, was the great Idukki dam project of the 1960s and 1970s which ran years over schedule because of labour disputes prolonged by a multiplicity of political influences. ${ }^{8}$ Kerala's coalitions have been unable both to act decisively and to enforce labour law strictly and effectively. Capital therefore avoids Kerala, and is invested in other states with majority governments able to discipline their citizens. So, at least, does this popular argument run.

\footnotetext{
6 Sen and Dreze, 1995: 51-6. Another phrase is ‘public politics’ (R. Jeffrey, 2001: 9-10).

7 See, for example, Tharamangalam (1998); Ramanathaiyer and MacPherson (2000).

8 There are benefits from such confrontations. In the 1980s, widespread protests blocked the Silent Valley dam project which would, most analysts now agree, would have been an environmental catastrophe.
} 


\subsection{Coalitions in India: Learnership and Leadership}

My argument is that at the national level India has followed a pattern similar to that of Kerala. Politicians and people associated with them have needed to learn how coalitions work and why there was personal benefit in making them work - or at least, considerable personal loss in having them fail. Accompanying the learning there needed to be the discovery of suitable coalition leaders with particular characteristics.

At the national level, indications that the 'one-party dominant' story of Indian politics was in its final stages came with the 1967 general elections, the first after the death of Jawaharlal Nehru (1889-1964). His daughter, Indira Gandhi (1917-84), installed by party bosses as a short-term expedient, led the Congress Party to a narrow victory with only 283 seats in a lower house of 516 members (though still with 41 per cent of the vote) (Butler, Lahiri and Roy, 1995). This was a loss of 80 seats and a majority of 'only' about 20 seats (though this would seem a huge cushion to later politicians). The Congress lost control of nearly half the Indian states at the same elections. It held 60 per cent of the total seats in state legislatures in 1962; the share fell to 48 per cent in 1967 (Guha, 2007). In the states, the process of coalition-learning began in earnest. The next four years became the era of 'aya ram aur gaya ram' - the time of legislators coming and going from one party to another as state governments rose and fell throughout the country.

What are my reasons for asserting that this period of instability was part of a learning process? Ideologically, some politicians, both of the left and right, were convinced that the purity of their parties' principles had to be asserted once a role in government was achieved. At the most obvious, Communist parties would not support a government that included the right-wing Jana Sangh, which, in turn, would not support a ministry that included Communists. Face-saving measures had yet to be devised that allowed governments to function, and benefits to flow, without sullying a party's ideological purity. Such examples developed in Kerala in 1969-70 when the Congress found it possible to support a CPI-led government 'from outside' the ministry until it became comfortable to join as full-scale coalition partners. Elsewhere, experience had to teach such practical devices and the benefits of ideological elasticity. Practically, newcomers to legislatures needed to experience both the fruits of office and the rapidity with which they could disappear. In the first flush of being elected, and being able for the first time to influence the making of a state government and the patronage available from it, these newcomers (or newly influential) tended to move eagerly from one alignment to another. But, over time, it became clear that constant movement usually led to dissolution of the legislature and new elections. An MLA then stood to lose the privileges of office and had the expense of fighting another campaign with no guarantee of winning. Indeed, in Kerala experience began to show that incumbency was more likely to be harmful to than helpful. These lessons, bitterly taught to Kerala’s politicians from 1948 to 1970, were learned in other Indian states between 1967 and 1977. At the national level, however, that process began in 1977, and fructified only in 1999.

There was a second element — leadership — that had to be understood. Again, instructive parallels emerge between Kerala and the national experience. Indira Gandhi had ruled with a minority government between 1969 and 1971 after the Congress Party split that she engineered. The first coalition government in New Delhi formed only in 1977 and was, in theory, a government of the Janata Party, hastily cobbled together when Mrs Gandhi ended her 19-month 'emergency' and called elections. The Janata Party was in fact a patchwork of the Jana Sangh, ex-Congress politicians and socialists. It had a number of aspirant Prime Ministers but no obvious 
choice, and the mantle finally fell on Morarji Desai (1896-1995), austere longtime Congress politician and Prime Ministerial aspirant since the time of Nehru. His pride and aloofness echoed characteristics of Pattom Thanu Pillai in Kerala. This was the wrong leader for the job. In 1979, his short-lived successor, Charan Singh (1902-87), was a wily regional politician, but lacking in the breadth of experience, contacts and perspective that are characteristics of the successful coalition leader in India.

The 1989-91 period provided a further, and perhaps seminal, lesson in this experience of 'learning coalitions'. Rajiv Gandhi’s huge Congress majority of 1984 (415 seats) crashed to a minority of 200 seats in 1989, and opposition parties struggled to form a government. This led to perhaps the most famous double-cross in modern Indian politics - and a lesson in the need for a basic level of probity if coalitions were to survive. V.P. Singh (b. 1931), the leading candidate, told his rival, Chandra Shekhar (1927-2007), that he, Singh, would withdraw from the contest for Prime Minister and support Devi Lal (1914-2001), a regional leader from north India. Singh did not tell Chandra Shekhar that Devi Lal would decline the office and nominate Singh — which was what happened, to Chandra Shekhar's surprise, in the crucial meeting (Malhotra, 2003). For coalitions to last, there need to be grounds for basic trust among the parties. The V.P. Singh coalition wrote a key entry about the downside of duplicity in the annals of national politics. The new coalition government lasted less than a year, and between 1989 and 1999 India experienced eight governments and seven Prime Ministers. ${ }^{9}$ The similarity with Kerala's experience is apparent.

This era of intense coalition-learning at the national level ended in 1999 with the formation of the coalition led by the Bharatiya Janata Party. Its longtime leader A.B. Vajpayee became Prime Minister and led the multiparty government through a full five-year term. The alliance consisted of 15 parties, four of which returned only one member to the Lok Sabha. They controlled about 300 seats in a lower house of 543 members, and Vajpayee formed a 70-member ministry, which aimed to balance regional, party and individual interests (Chander, 2004). The government alliance went united, if somewhat realigned, into the 2004 elections, which it lost to the rival Congress-led alliance, again suggesting a pattern similar to that of Kerala.

It was not the mechanics of the coalition - the various balancing acts - that was, in my view, the key ingredient of the survival of the Vajapayee government of 1999-2004. Stability resulted in part from the dearly won awareness of legislators that to be in office was better than being out of it - the lessons of the previous ten years. But what had to be added were the characteristics that Vajpayee brought to the prime ministership. Though his ideological background was different, he had a number of similarities with Achutha Menon. Vajpayee (b. 1924) was 72 in 1999, and though apparently in good health was usually able to make clear to coalition members that they needed him more than he, at his age, needed them. His years of grassroots politics gave him a network and aplomb that allowed him to meet people and resolve differences with ease. He was recognised as someone who had earned his spurs and paid his dues. These have emerged as the qualities of a successful Indian coalition leader: urbanity, probity (or a reputation for it), reputation for achievement (probably in politics) and an apparent willingness for renunciation — to be able to walk away from the job if colleagues do not measure up.

\footnotetext{
9 Rajiv Gandhi, V.P. Singh, Chandra Shekhar, P.V. Narasimha Rao, H.D. Deve Gowda, I.K. Gujral and A.B. Vajpayee.
} 
Manmohan Singh (b. 1932), Vajpayee's successor after the Congress-led coalition's narrow victory in the 2004 general elections, may seem an unlikely comparison with Vajpayee. An economist trained in Punjab and at Cambridge and Oxford, he spent part of his working life abroad working for the IMF. Until 1989, he was an official, a former Governor of the Reserve Bank of India. It was a career in marked contrast to Vajpayee’s devotion to the cause of Hindu-oriented politics. Manmohan Singh, however, has other characteristics in common with those of successful coalition leaders. First, in the timing of his coming to office, he has benefited from the lesson-learning that national politicians have undergone about the brevity of political life, the fruits of public office and the need for a certain stability if fruits are to be enjoyed. He has had to deal with less fractious colleagues than those who sought to build coalitions from the 1970s to the 1990s. Second, he has standing and reputation, though different from those of an Achutha Menon or Vajpayee who earned theirs in the hard scrabble of longtime politicking. His international experience, and his experience at the top of the bureaucratic tree, command respect. As a Sikh, he is 'a minority', which implies an ability to mix with both the 83 per cent 'majority' of 'Hindu India' and the other 17 per cent, the so-called 'minorities.' He has the ease and openings with a wide variety of people that Achutha Menon acquired as jailbird Communist and Vajpayee as a relentlessly campaigning politician.

Finally, Manmohan Singh came to the Prime Ministership in an unusual way, the surprise nominee of Sonia Gandhi, president of the Congress Party. At one level, it can be said that he has no political base and could not hope to win an election in his own right. On the other hand, his qualities are rare. Just as Achutha Menon and Vajpayee were able to play a card that said, 'If not me, who?', so too can Manmohan Singh. He can also do as they did: give the impression of readiness to be a renouncer - to leave the post if political turmoil becomes unacceptably great.

In summary, my argument is that people in politics need to learn through experience the conventions of successful coalition government. That experience came first in the state of Kerala through the 1950s and 1960s. At the national level, the lesson began in 1977 and resumed in 1989. An aspect of this experience is the discovery that a particular kind of leader is necessary to make coalitions stick. Such leaders cannot be stiff, aloof, doctrinaire and narrow (on the lines of Pattom Thanu Pillai and Morarji Desai). Rather, they require an ease, broad experience and a hint of reluctance sufficient to make the fractious fear a resignation. These two sets of circumstance - learnership and leadership — are not the sole ingredients of coalition-building; but they are important aspects that have tended to be overlooked.

\subsection{The Consequences of Coalitions: India}

Does my tentative conclusion that in Kerala, coalition government has been better for social development than economic development apply equally to the Indian experience? With great tentativeness, let me suggest that they do.

At the most general level, the decade 1991-2001 saw some of the most notable improvements in social statistics in post-independence history in a number of states. To choose two small but significant examples, in Rajasthan and Uttar Pradesh, neither state noted for its cutting-edge modernity, literacy rates grew from 39 per 
cent to 61 per cent and 41 per cent to 57 per cent, respectively, between 1991 and 2001. ${ }^{10}$ Superficial observation suggests that similar advances were seen in other states and in other areas of individual well-being such as infant mortality. This is not to argue that the uncertainty of coalitions means that members of the national parliament rush round their constituencies to ensure that schools are attended, mothers and babies looked after and roads and bridges built and that their diligence results in notable change. Rather, it is to argue that coalitions at the national level do no harm to such processes and may indeed do them some good. The reasons are similar to those for Kerala in the 1960s and after. As politicians become increasingly aware of the tenuousness of their hold on office, they search for ways to improve their chances. Pleasing their constituents is one such way. The uncertainty of coalitions brings attention and diligence.

For economic development, coalition governments are generally perceived as a negative force. According to such a view, their multi-faceted fragility make them indecisive, unable to take big decisions and inclined to resile even on the decisions they make. This point is often made in contrasting India's economic development in the past 20 years with China's, where roads get built, rivers dammed and labour deals done with far greater speed and predictability.

It needs to be noted, however, that it was a fragile minority government that pursued the economic liberalisation program that began in $1991{ }^{11}$ From 1996, India has known only coalition governments, yet the period is usually described as the most economically dynamic since independence.

The short answer to the question, 'Are coalitions bad for economic development?', may be that for 21st century India there is no alternative. Two factors suggest this. First, India is socially segmented — by language, religion, region and caste. Second, growing literacy, mobility and media penetration mean that larger proportions of the population than ever before are able to compare their circumstances and needs with others and to seek ways of changing their lot. Such political mobilisation usually occurs where it seems most meaningful — at the locality or the region. Thus we see, even within states, localised political groups. Such patterns are repeated for national elections. The current national government of the 'United Progressive Alliance' of 2007 had a dozen parties supporting it, plus 'outside' support from four Left parties ${ }^{12}$ and the Bahujan Samaj Party, the Dalit-based party of Uttar Pradesh (a considerable force with 19 seats in the Lok Sabha). The previous BJP-led government similarly had more than a dozen constituents.

It is not impossible that the BJP, the Congress or indeed, a new formation could galvanise the country and win an absolute majority in national elections. Half of India now goes home each night to a place with a television set. ${ }^{13}$ All-India messages can be shared simultaneously as never before, and an exciting personality, perhaps from the media (an M. G. Ramachandran or an N.T. Rama Rao) could conceivably create a wave of enthusiasm. But at a national level this will be exceedingly difficult. The nature of Indian society makes the coalition formula seem likely to last.

This is not necessarily a bad thing, even for economic development. Now that many of the lessons of sustained coalition government have been learned, including identification of appropriate qualities in a coalition

\footnotetext{
10 Statistical Outline of India, 2003-04, p. 126.

11 Guha, India after Gandhi, p. 637. Congress won 244 seats in the 1991 elections and depended on independents and small regional groupings for its majority in the Lok Sabha.

12 Communist Party of India (Marxist), Communist Party of India, All-India Forward Bloc, Revolutionary Socialist Party.

13 Based on an estimate of 110 million television households with 5.5 people per household.
} 
leader, coalition governments may be expected to survive their full terms and thus provide continuity of policy. The Kerala example suggests — and Indian experience since 1991 tentatively confirms — that coalitions, and the attentive-to-their-electorate politicians they promote, may contribute positively to social development.

Moreover, the uninspiring economic story of Kerala is unlikely to be repeated nationally. The business traditions, and hold of globalised capitalism, in other parts of India will continue to impel economic change. The disparate forces driving such change are more powerful than the disparate forces that would restrain it. And national governments, intent for example on winding up unprofitable state-owned industries, will take advantage of the country's diversity. A closure in one corner of the country may incense local political parties, but they will find it difficult to win much support from regional parties elsewhere. Thus some economic change may go ahead piecemeal and almost by stealth. This is not Chinese-style 'decisive government'; but once learnership and leadership are in place coalition governments in India appear capable of both surviving and delivering sustained, though unspectacular, social and even economic change.

\section{Bibliography}

Books

Adeney, Katharine, and Lawrence Saez. Coalition Politics and Hindu Nationalism. 1st ed. New York: Routledge, 2005.

Bueno de Mesquita, Bruce. Strategy, Risk, and Personality in Coalition Politics: The Case of India. Cambridge; New York: Cambridge University Press, 1975.

Chakrabarty, Bidyut. Forging Power: Coalition Politics in India. New Delhi; New York: Oxford University Press, 2006.

Chander, N. Jose. Coalition Politics: The Indian Experience. New Delhi: Concept Pub. Co., 2004.

Deepak, Om Prakash, and Christian Institute for the Study of Religion and Society. The Coalition Government: A Critical Examination of the Concept of Condition, the Performance of Some Coalition Governments, and the Future Prospects of Coalition in India. Madras: Published for the Christian Institute for the Study of Religion and Society, Bangalore, by the Christian Literature Society, 1974.

Jai, Janak Raj, and Rajiv Jai. Political Trends: Revival of Two Party System in India: Ruling vs. Combined Opposition. New Delhi: Regency Publications, 1999.

John John, P. Coalition Governments in Kerala. Trivandrum: Institute for the Study of Public Policy and Management, 1983.

Karunakaran, Kotta P. (editor). Coalition Governments in India: Problems and Prospects. Simla: Indian Institute of Advanced Study, 1975.

Kohli, Atul. Democracy and Discontent: India's Growing Crisis of Governability. Cambridge; New York: Cambridge University Press, 1990.

Kumar, Arun. On Coalition Course. New Delhi: Press Trust of India in association with Gyan Pub. House, 1998.

Kumar, Sunil. Parties and Coalition Politics: A Comparative Study. New Delhi: Uppal Publishing, 2004.

Pakem, B. Coalition Politics in North-East India. New Delhi: Regency Publications [for] Indian Council of Social Science Research-North-Eastern Regional Centre, c1999.

Pandey, Jawaharlal. State Politics in India: A Study in Coalition Politics in an Indian State. New Delhi: Uppal, 1982.

Roy, Ramashray, and Paul Wallace (editors). India's 2004 Elections: Grass-Roots and National Perspectives. New Delhi; Thousand Oaks, Calif.: Sage Publications, 2007.

Sahni, Naresh Chander (editor). Coalition Politics in India. Jullundur, New Academic Pub. Co., 1971.

Singh, Mahendra Prasad, and Anil Mishra (editors). Coalition Politics in India: Problems and Prospects. New Delhi: Manohar, 2004.

Sundar Ram, D. Coalition Politics in India: Search for Political Stability. Jaipur: National Pub. House, 2000. Thakurta, Paranjoy Guha, and Shankar Raghuraman. A Time of Coalitions: Divided We Stand. New Delhi; Thousand Oaks, Calif.: Sage Publications, 2004.

Thomas, E. J. Coalition Game Politics in Kerala. 1st ed. New Delhi: Intellectual Pub. House: sole distributors, Intellectual Book Corner, 1985. 


\section{Book chapters}

Van Dyke, Virginia. “'Jumbo Cabinets” Factionalism, and the Impact of Federalism: Comparing Coalition Governments in Kerala, Punjab, and Uttar Pradesh.’ In India's 2004 Elections: Grass-Roots and National Perspectives, edited by Ramashray Roy and Paul Wallace. New Delhi; Thousand Oaks, Calif.: Sage Publications, 2007.

Swamy, Arun R. "Sense, Sentiment and Populist Coalitions: The Strange Career of Cultural Nationalism in Tamil Nadu." In Subnational Movements in South Asia, edited by Subrata K Mitra and R. Alison Lewis. Boulder, Colo.: Westview Press, 1996, pp. 191-236.

\section{Journal articles:}

"Leaders: Who, Me? - Who, Me?; India's Election." The Economist 371, no. 8376, (May 22, 2004): 10.

Ahmed, Farzand. "Down and out; the JMM Supremo's Conviction Has Rocked the UPA Boat at the Centre and in Jharkhand." India Today (December 11, 2006): 22.

David, Stephen. "Deccan Dynasty; the Deve Gowda Clan Gets a Second-Generation Chief Minister Who Is at Odds with the First. But Problems Could Soon Arise as Coalition Partner BJP Is Not Likely to Play Second Fiddle for Long." India Today (February 13, 2006): 48.

— . "His Father's Son; Karnataka's First Shot at Coalition Politics Fails as Deve Gowda's Son Walks out on the Congress-JD(S) Government. Waiting in the Wings Is the BJP for Its First Taste of Power in the South." India Today (January 30, 2006): 49.

Karp, Jonathan. "Muddled Mandate." Far Eastern Economic Review 159, no. 21 (May 23, 1996): 16.

Kohli, Atul. "Enduring Another Election." Journal of Democracy 9, no. 3 (July, 1998): 7-20.

Kuruvilla, C P. "Comeback Dreams." Far Eastern Economic Review 160, no. 3 (January 16, 1997): 22.

McDonald, Hamish. "India: Revivalist Retreat." Far Eastern Economic Review 156, no. 49 (December 9, 1993): 18.

Nikolenyi, Csaba. "The New Indian Party System: What Kind of a Model?" Party Politics 4, no. 3 (1998): 36780.

Schaffer, Teresita, and Hemani Saigal-Arora. "India: A Fragmented Democracy." The Washington Quarterly 22, no. 4 (Autumn, 1999): 143-50.

Seshia, Shaila. "Divide and Rule in Indian Party Politics: The Rise of the Bharatiya Janata Party." Asian Survey 38, no. 11 (November, 1998): 1036-50.

Sridharan, Eswaran. "Coalitions and Party Strategies in India's Parliamentary Federation." Publius 33, no. 4 (Fall, 2003): 135-52.

Wilkinson, Steven. "Social Cleavages and Electoral Competition in India." India Review 2, no. 4 (October, 2003): 31-42. 